\title{
Preliminary Study on the Development of Book Reviewed from the Value of the Character of Students of Physics Education of the Faculty of the State University of Medan
}

\author{
Sondang R Manurung ${ }^{1}$, Mara Bangun Harahap ${ }^{2}$ \\ \{sondangmanurung@unimed.ac.id \} \\ Faculty of Mathematics and natural Sciences, Universias Negeri Medan, Medan, Indonesia ${ }^{1,2}$
}

\begin{abstract}
This research is a preliminary research study of the development of books general physics and students worksheet based on inquiry to improve the thinking skills and value of character of physics education students of FMIPA Medan State University. This research is an $\mathrm{R} \& \mathrm{D}$ research which includes three stages of research, namely: 1) Preliminary Study, 2) Development of books and students worksheets, and 3) Trial of books and students worksheets. The preliminary study was carried out in a) library analysis and b) questionnaire sheets. Library analysis to study syllabi on the of magnetic electric waves and about inquiry learning in terms of character basis. The questionnaire sheet was given to students of the 2017/2018 class physics education program and a field survey of the lecturers of basis of magnetic electric waves courses by giving questionnaires to 3 lecturers. The results of the study showed that the basic course of basis of magnetic electric waves based on inquiry can improve character. The character of students can increase from the habit of conducting inquiry activities in their learning. The results of the preliminary study show that learning outcomes of students tended to be low with poor character.
\end{abstract}

Keywords: Reviewed, Value Character, Students, Physics Education.

\section{Introduction}

As the Indonesian National Qualifications (KKNI) framework based curriculum is valid at the State University of Medan, most of the names of courses also experience changes such as General Physics II, the name of which is the magnetic wave base of one of the courses taught in all MIPA study programs. This is done on the basis of changes, development and innovation in each study program that is required to clarify the "graduate profile" which is expected through the activities of tracking studies, feasibility studies and needs analysis in the community. The graduate profile reflects the minimum ability that students must master after graduation which refers to four aspects of needs. The material in General Physics II are: 1) Vibration, 2) Waves and Sounds, 3) Optical Geometry, 4) Electricity, 5) Alternating Current and Voltage, and 6) Quantum Symptoms \{KurikulumFisika KKNI 2016). So far, some lecturers have taught general physics material II by lecturing, discussion, assignment and rarely use a student centered approach (student-centered learning) which causes student difficulties in understanding physical symptoms (Manurung, 2014). In order for general 
physics concepts II to be understood by students, there needs to be innovation in lectures. One of the innovations in the lecture was the existence of a textbook based on inquiry-based electricity wave courses (Manurung,2015; Abdi, 2014., Lawson, 2010).. Inquiry learning innovation improves character Sarwi,dkkr (Diani, 2015; Sawidkk, 2018) and thinking skills, mastery of knowledge, concepts, and physical principles, skills in developing knowledge, skills and self-confidence can be applied in everyday life and as a provision for continuing higher education is one of the physics learning objectives listed in the curriculum (DirjenDikti 2009). Textbooks are very useful to use in learning (PPS Unibraw, 2010). Physics learning materials will be more quickly understood if applied inquiry learning (Joyce \& Weil, 2009., Arends, 2012). This is supported by the opinion of Ausubel (Dahar, 1989), and Antony Robbins (dalamTrianto, 2009) "Learning is the process of creating a relationship between knowledge that has been understood and something new knowledge". The inquiry approach is based on experimental activities in the laboratory, namely formulating hypotheses and investigativeactivities. This activity educates students to have good character values, namely coriusity, honesty, cooperation, logical thinking, critical, creative, and innovative, healthy lifestyle, confidence, respect for diversity, discipline, independent, responsible, care for the environment, love science.Lickona (1991). states that character education is a deliberate effort to help someone so that he can understand, pay attention to, and carry out core ethical values. Character education values can be integrated into the learning process, including in physics learning (Gunawan, 2012., Undang- Undang, 1989).

\section{Methods}

This research includes research and development. Type R \& D research is a process used to develop and validate educational productsSani,dkk, 2017). in this study an inquiry-based book product for physics learning will be developed. in general, the research was carried out in 3 stages, namely: preliminary study phase, stage of inquiry-based book design development for physics learning, and model validation and evaluation stages at present the research is still in the preliminary study stage. at this stage the method used is descriptive method researchers can directly relate to respondents and other objects related to the problem under study.

\section{Result and Discussion}

\subsection{Needs Analysis}

Needs analysis is carried out through preliminary studies at one of the state universities in north sumatra. this activity is intended to get an idea of what students need as candidates for physics teacher and can be fulfilled through basic lectures of electric and magnetic waves, what is the condition of the electrical and magnetic wave elementary courses that have been carried out, the available learning facilities, and the student background reviewed from the ability of the thinking process, and its character. 


\subsection{Student Needs Analysis}

According to minister of National Education Regulation number 16 of 2007 (Permendiknas, 2007), for the dimensions of professional competence, a teacher must be able to: 1) master the material, structure, concepts, and scientific mindset that supports the subjects being taught;2) master the competency standards and basic competencies of the subjects being taught; and 3) developing creative learning material. mastery of these three things in physics teachers must be supported by subjects that underlie the field of physics, including basic courses in electric and magnetic waves. at this level, the needs of prospective physics teacher students for the basic lectures of electric and magnetic waves are the ability to apply physical concepts in everyday life and technology. the ability to apply this physics concept mainly supports the dimension of the ability to develop learning materials creatively and innovatively.

\subsection{Content Analysis}

Students who have good thinking skills, enable them to develop an understanding of the concept. Concept understanding needs to be developed because of the five cognitive processes (understanding, applying, analyzing, evaluating, and creating) that are based on transfer ability and emphasized in schools and universities are understanding Manurung, 2016., Manurung, 2016.,Saputri dkk, 2016., Sever \&Guren, 2014). One of the main functions of the electrical and magnetic wave basic lectures is to equip the physics teacher candidates in developing the understanding of the concept (NSTA, 2003.,Klauz\& Horn, 2014., Wilkinson, 2010., Stein, 2015). Students are said to understand if they can construct the meaning of learning messages, both oral, written, or graphic. Material delivered through teaching, books, or multimedia. Understanding concepts in Electric and magnetic waves, among others, are realized in a number of abilities in terms of: interpreting, giving examples, classifying, comparing, explaining, and concluding Analysis of lecture conditions of basic waves electric magnetic for physics teacher candidates at one of the state universities in North Sumatra have a weight of 3 credits. Based on the weight of this credits, basic electrical and magnetic wave lectures are carried out with a lecture system ( 2 x 50 minutes / week as many as 16 meetings including formative examinations). Lecture with the ratio of lecturers to students 1:50. Practicum activities are carried out separately, with a ratio of 1:50 lecturers to students for $2 \times 50$ minutes / week. Lecture and practicum sessions are taught by one lecturer. The source of learning lectures uses books developed by lecturers plus other reference books.

\subsection{Character Value Analysis}

Physics learning requires students to have a scientific attitude (William, 1993., Koc\& Liu, 1994., Kalman, 1961) which will cause them not to be prejudiced in making decisions, tolerant, honest, responsible, respecting the opinions of others is the character's value. Practicum activities in the laboratory are carried out in accordance with standard operating procedures, so before conducting practicum students must read and obey the work rules in the laboratory to maintain workplace safety and security (discipline value). With the practicum instructions that have been provided they do the preparation / set of tools according to the instructions together (value of work), one member helps the other, then performs data collection (independent, love of knowledge) both by measurement and reading carefully so that the data obtained valid and can be analyzed (respecting diversity, business value and responsibility) without being affected by the results of each other (the value of confidence and 
honesty). The data that has been obtained is then analyzed together by conducting discussions (critical, logical thinking, innovative) which are then )used to compile reports (confident, creative).

\subsection{Character Indicators and How to Train}

From the results of the practicality test through observation sheets 10 character behaviors for 10 respondents (score range $0-4$ ) obtained data as shown in Table 1.

Table 1: Score of character indicators and how to train them [30,31]

\begin{tabular}{|c|c|c|c|c|}
\hline No & $\begin{array}{l}\text { character } \\
\text { indicators }\end{array}$ & $\begin{array}{l}\text { Average } \\
\text { score }\end{array}$ & category & $\begin{array}{l}\text { How to train character } \\
\text { indicator }\end{array}$ \\
\hline 1 & $\begin{array}{l}\text { careful and } \\
\text { serious }\end{array}$ & 3,6 & Very high & $\begin{array}{l}\text { Pay close attention and note when } \\
\text { the lecturer explains everything } \\
\text { related to teaching material }\end{array}$ \\
\hline 2 & responsible & 3,6 & Very high & $\begin{array}{l}\text { In carrying out their duties and } \\
\text { obligations as they should and } \\
\text { when students conduct } \\
\text { experimental activities are trained } \\
\text { to be careful when working with } \\
\text { tools and materials, carry out } \\
\text { activities in accordance with the } \\
\text { procedures provided and can } \\
\text { carry out tasks in accordance with } \\
\text { the division of labor }\end{array}$ \\
\hline 3 & polite & 3,6 & Very high & $\begin{array}{l}\text { Speak and behave to all people } \\
\text { well and smoothly, and when } \\
\text { asking and expressing opinions } \\
\text { politely, behaving well and using } \\
\text { good language so as not to offend } \\
\text { others in taking data during } \\
\text { practicum and doing individual } \\
\text { tasks. }\end{array}$ \\
\hline 4 & honest & 3,6 & Very high & $\begin{array}{l}\text { In taking data during practicum } \\
\text { and doing individual tasksdalam }\end{array}$ \\
\hline 5 & careful & 3.6 & Very high & $\begin{array}{l}\text { In an experimental activity where } \\
\text { this behavior is shown from the } \\
\text { actions of students in taking step } \\
\text { of work on careful and earnest } \\
\text { and recording the results of } \\
\text { observation. }\end{array}$ \\
\hline 6 & cooperate & 3,1 & High & $\begin{array}{l}\text { This character is trained in } \\
\text { students in shaping behavior in } \\
\text { themselves to establish } \\
\text { relationships with other people } \\
\text { and in group activities and } \\
\text { discussions where this character } \\
\text { can be demonstrated through the } \\
\text { actions of students including not } \\
\text { dominating the lesson, being able } \\
\text { to provide assistance or asking for } \\
\text { help and sharing information. }\end{array}$ \\
\hline 7 & Confidence & 3,2 & High & $\begin{array}{l}\text { To form an attitude of confidence } \\
\text { in one's own abilities trained } \\
\text { through question and answer } \\
\text { activities, discussions, } \\
\text { experiments and in examinations. }\end{array}$ \\
\hline
\end{tabular}




\begin{tabular}{|c|c|c|c|c|}
\hline & & & & $\begin{array}{l}\text { Students dare to express their } \\
\text { opinions, dare to answer } \\
\text { questions and be able to do things } \\
\text { confidently. }\end{array}$ \\
\hline 8 & $\begin{array}{l}\text { Mutual } \\
\text { respect }\end{array}$ & 4 & Very high & $\begin{array}{l}\text { This character is trained in } \\
\text { students to form an attitude of } \\
\text { respect and acknowledge } \\
\text { everything that is conveyed by } \\
\text { others. In discussion activities } \\
\text { where actions that show this } \\
\text { character can appreciate the } \\
\text { opinions of others who are } \\
\text { different, acknowledge the } \\
\text { advantages of others, and can } \\
\text { accept if their opinions are not } \\
\text { accepted by others. }\end{array}$ \\
\hline 9 & $\begin{array}{l}\text { independen } \\
\mathrm{t}\end{array}$ & $1,, 9$ & Low & $\begin{array}{l}\text { This character is trained in } \\
\text { shaping attitudes and behaviors } \\
\text { that are not easily dependent on } \\
\text { others in completing tasks. In } \\
\text { learning, this character can be } \\
\text { trained in evaluation activities } \\
\text { including giving exercises, oral } \\
\text { questions, examinations and } \\
\text { homework. Students are able to } \\
\text { make their own assignments, do } \\
\text { not ask questions during exams, } \\
\text { and believe in their own abilities. } \\
\text { The low observation results for } \\
\text { independent characters in the } \\
\text { above practicalities are due to } \\
\text { evaluation activities carried out } \\
\text { only through several questions } \\
\text { verbally so that only a few } \\
\text { students are appointed to answer. }\end{array}$ \\
\hline 10 & democratic & 3 & High & $\begin{array}{l}\text { This character is trained in } \\
\text { shaping ways of thinking, acting, } \\
\text { and acting that assess the rights } \\
\text { and obligations of himself and } \\
\text { others. In learning activities, this } \\
\text { character can be trained in group } \\
\text { activities and discussion. Actions } \\
\text { that show this character are } \\
\text { owned by students including in } \\
\text { doing assignments in groups of } \\
\text { students can provide } \\
\text { opportunities for friends to } \\
\text { actively express opinions, in the } \\
\text { discussion can express opinions } \\
\text { which are a collection of some } \\
\text { friends in groups, do assignments } \\
\text { in groups according to the } \\
\text { division of tasks. }\end{array}$ \\
\hline
\end{tabular}

Learning Implementation base on RPP that is made by teacher, with always gives character values base on learning material given provided by the teacher and familiarized in their daily lives (Prihartini, 2013). 


\section{Conclusion}

Character education is a potentially powerful tool in the critical process of child and adolescent development, a process in which schools must (and inevitably will) play a central role.

Acknowledments. The research is funded by the Competitive Grants DP2M Director General of Higher Education Ministry of Education and Culture. Therefore, researchers who receive grants DP2M to thank the Director General of Higher Education which has provided funds, and the opportunity for researchers to conduct research in Physical Education Program, Unimed. On this occasion, the authors would like to thank the Rector and Chairman of the Research Institute of the State University of Medan which has given opportunity to the team of researchers to conduct research

\section{References}

[1]Abdi, A .: The Effect Of Inquiry-Based Learning Method On Students' Academic Achievement In Science Course. Universal Journal of Educational. 2(1): 37-41 (2014)

[2]Arends, R. I. 2012. Learning to Teach Ninth Edition, New York, McGraw Hill

[3] B. Klaus and P. Horn.: Robot Vision. Cambridge, MA: MIT Press(2014)

[4] Diani,R.: Pengembangan Perangkat Pembelajaran Fisika Berbasis Pendidikan Karakter Dengan Model: Problem Based Instruction. Jurnal Ilmiah Pendidikan Fisika 'Al-Biruni'4 (2) 243-255 (2015)

[5] DirjenDikti.: Kerangka Acuan Pendidikan Karakter. Jakarta (2010)

[6] Gunawan, H.: Pendidikan Karakter Konsep dan Implementasi. Alfabeta: Bandung. (2012)

[7] Joyce.W.: Models of Teaching. Yogyakarta: Pustaka Pelajar. (2009)

[8] J. P. Wilkinson.: "Nonlinear resonant circuit devices," U.S. Patent 3624 125, July 16. (2010)

[9] J. O. Williams .: "Narrow-band analyzer," Ph.D. dissertation, Dept. Elect. Eng., Harvard Univ., Cambridge, MA (1993)

[10] Jurusan Pendidikan Fisika FMIPA Unimed. Kurikulum Fisika KKNI (2016)

[11] Lawson, A. E.: Teaching inquiry science in middle and secondary schools.California: Sage (2010)

[12] Lickona, T. 1991.: Educating for Character: How Our School Can Teach Respect and Responsibility.New York: Bantam Books.(2004)

[13] L. Stein, "Random patterns," in Computers and You, J. S. Brake, Ed. New York: Wiley, pp. 55$70(2015)$

[14] Manurung, S. R.: Eksplorasi Kemampuan Pemecahan Masalah Dalam Topik Kinematika Bagi Mahasiswa Calon Guru. Prosiding Simposium Fisika Nasional XXVII "Fisika dalam Kehidupan Sehari-hari". (2014)

[15] Manurung, S. R.: Improvement of Problem Solving Ability in Kinematics Through Learning Model Based on Problem Solving Pedagogy. Proceeding The 2nd Annual International Seminar on Trends in Science and Science Education (2015) 
[16] Manurung, S. R.: Pengembangan Pembelajaran Fisika Berbasis Argumentasi Ilmiah Dalam Kelas Inkuiri Untuk Meningkatkan Pemahaman Konsep. Prosiding Bidang Fisika Semirata Tahun (2015)

[17] Manurung, S. R.: Pengembangan Model Pembelajaran Fisika Berbasis Multi Media Interaktf Bermuatan "Problem Solving" (MMI-PS) Untuk Meningkatkan Kemampuan Berpikir Mahasiswa Calon Guru (Development), Penelitian. Unimed (2016)

[18] Manurung, S. R.: Improving the Conceptual Understanding in Kinematics Subject matter with Hypertext Media Learning and Formal Thinking Ability.Journal of Education and Practice.7(9). (2016)

[19] National Standart Teacher Asisiation 2003, "Standard For Science Teacher Preparation http://www.nsta.org/preservice, (diakses tanggal 27 Agustus 2014)

[20] PPS Universitas Brawijaya.: Pedoman Umum Penulisan Bahan Ajar.Malang: Universitas Brawijaya. Permendiknas nomor 16 tahun 2007 (2010)

[21] Prihatini, L. 2013.Character-Based Learning Management Of Physics: A Site Study At SMK Muhammadiyah 1 Blora.http://eprints.ums.ac.id/24266/15/Naskah_Publikasi.pdf ,(diakses tanggal 2 Pebruari 2018)

[22] Ratna Wilis Dahar.: Teori-Teori Belajar. Jakarta: Erlangga (1989)

[23] R. E. Kalman.: "New results in linear filtering and prediction theory," J. Basic Eng. 83 (4), pp. 95-108 (1961)

[24] Sani, R.A, dan Manurung,S.R, Suswanto,H, danSudiran.: Penelitian Pendidikan. Tangerang: Tira Smart. (2017)

[25] Saputri, D. F., Syarifah and F., Wahyudi.: Efektivitas Penggunaan Buku Ajar Fisika Matematika Berbasis Inkuiri Dalam Perkuliahan Fisika Matematika. Jurnal Penelitian \& Pengembangan Pendidikan Fisika (JPPPF). 2(2): 7-14 (2016)

[26] Sever, D \&Güven, M.: Effect of Inquiry-based Learning Approach on Student Resistance in a Science and Technology Course.Educational Sciences: Theory \&Practice .14(4): 1601-1605 (2014)

[27] S Sarwi1,* , N Fauziah2 and B Astuti1 (2018):The analysis of scientific communications and students' character development through guided inquiry learning. Journal of Physics: Conf. Series983 (2018) 012031

[28] Trianto.: Mendesain Model Pembelajaran Inovatif-Progresif (2009)

[29] Undang-Undang No.2/1989

[30] U. V. Koc and K. R. Liu.: "Discrete-cosine/sine-transform based motion estimation," in Proceedings of the IEEE International Conference on Image Processing, Austin, TX, vol. 3, pp. 771 775.(1994) 